Article

\title{
Interactive Effect of Nitrogen and Azoxystrobin on Yield, Quality, Nitrogen and Water Use Efficiency of Wild Rocket in Southern Italy
}

\author{
Vincenzo Candido ${ }^{1, *}$, Francesca Boari ${ }^{2}$, Vito Cantore ${ }^{2}\left(\mathbb{D}\right.$, Donato Castronuovo ${ }^{1}(\mathbb{D}$, \\ Donato Di Venere ${ }^{2}$, Michele Perniola ${ }^{3}$, Lucrezia Sergio ${ }^{2}$, Roberto Viggiani ${ }^{1}$ and \\ Maria Immacolata Schiattone ${ }^{1, *}$ \\ 1 School of Agriculture, Forest, Food and Environmental Sciences, University of Basilicata, Viale dell'Ateneo \\ Lucano, 10, 85100 Potenza, Italy; donato.castronuovo@unibas.it (D.C.); roberto-vig@tiscali.it (R.V.) \\ 2 Institute of Sciences of Food Production, National Research Council (CNR-ISPA), Via Amendola, 122/O, \\ 70125 Bari, Italy; francesca.boari@ispa.cnr.it (F.B.); vito.cantore@ispa.cnr.it (V.C.); \\ donato.divenere@ispa.cnr.it (D.D.V.); lucrezia.sergio@ispa.cnr.it (L.S.) \\ 3 Department of European and Mediterranean Cultures, University of Basilicata, Via Lanera, 10, \\ 75100 Matera, Italy; michele.perniola@unibas.it \\ * Correspondence: vincenzo.candido@unibas.it (V.C.); mary.schiattone@libero.it (M.I.S.)
}

Received: 14 May 2020; Accepted: 12 June 2020; Published: 14 June 2020

\begin{abstract}
Wild rocket (Diplotaxis tenuifolia L. DC) is an emerging vegetable which market requires high-quality standards that can be obtained through appropriate cultivation techniques such as the right level of nitrogen and the application of biostimulant substances. These include strobilurins, marketed mainly as fungicides that can have complementary positive effects on the yield, quality and resources' use efficiency of many crops. For this reason, a trial in an unheated greenhouse, in Southern Italy, to evaluate the possibility of using Azoxystrobin to improve the production of wild rocket subjected to different nitrogen inputs, was carried out. Two $\mathrm{N}$ levels (40 and $\left.140 \mathrm{~kg} \mathrm{ha}^{-1}\right)$, Azoxystrobin-based biostimulant (Azo+) and control without Azoxystrobin (Azo-) were compared. The yield, morphological characteristics, nitrogen and water use efficiency (NUE, WUE), antioxidant activity, the content of dry matter, chlorophyll, carotenoids, phenols, and nitrates were assessed. A higher $\mathrm{N}$ level resulted in a $16.3 \%$ yield increase that was matched by a $12.5 \%$ reduction in NUE, $15.8,7.3$, and $16.1 \%$ increases in yield WUE (Y_WUE), biomass WUE (B_WUE), and irrigation yield WUE (IY_WUE), respectively, and a worsening of some qualitative characteristics such as a $8.5 \%$ rise in nitrates, and a decline by $11.5,10.1$, and $26.1 \%$ in the carotenoids, phenols, and antioxidant activity, respectively. Azo+ increased the yield by 10.3\%, NUE by 8.9\%, and Y_WUE, B_WUE, and IY_WUE, by $13.9,9.1$, and $13.8 \%$ respectively. Moreover, Azo+ improved some qualitative characteristics such as total phenols $(+9.4 \%)$, chlorophyll $(+15.2 \%)$, carotenoids $(+9.7 \%)$, and antioxidant activity $(+17.4 \%)$, while it did not affect the nitrate content. Azoxystrobin can be an additional tool available for farmers to ensure high-quality standards of wild rocket.
\end{abstract}

Keywords: Diplotaxis tenuifolia; strobilurin; biostimulant; WUE; NUE

\section{Introduction}

Diplotaxis tenuifolia (L.) DC is a species belonging to the Brassicaceae, whose Italian trivial name of 'rucola selvatica' (wild rocket) is prevalent, while the specific trivial name of 'perennial wallrocket' is used to discriminate it from other species of genus Diplotaxis [1]. Wild rocket was converted from a wild edible species to an interesting crop about twenty-five years ago, covering a recently estimated surface of about 4800 ha in Italy [2]. It has been drawing attention from vegetable operators due to its 
climatic resilience, successful yield performances, and profitability [3,4]. Wild rocket goes through several growing cycles thanks to its adventitious buds disseminated on its roots. New buds and shoots emerge at the plant's base thanks to the storage and utilization of carbohydrate reserves in taproot, leading to plant regrowth upon leaf cutting done at $3-5 \mathrm{~cm}$ above the soil surface [5]. For this reason, the same plants can give $2-5$ production cycles, even if the product with the best external characteristics generally is obtained from the first harvest.

The growing consumption of this vegetable derives from the particular organoleptic and nutritional features that meet the rising demand for new foods with improved nutritional characteristics. In particular, wild rocket is characterized by a unique aroma and piquant flavor, and can be eaten raw in salads or cooked in many recipes [6]. Compared to other leafy vegetables, wild rocket has a high content in iron, fiber, phenols, ascorbic acid, sterols, fatty acids, carotenoids, and glucosinolates, which are often ascribed as important bioactive properties (e.g., antioxidant, antitumor, etc.) [7-10].

The economic interest in the cultivation of wild rocket is currently growing. The increasingly widespread consumption of ready-to-use vegetables contributes significantly to this, favoured by their practicality, the variety of combinations of different species, the freshness, and often the very captivating presentation. The ready-to-use leaf vegetable market is increasingly appreciating the baby leaf product type, to which wild rocket is very suitable [11].

The ready-to-use market requires a product with high-quality standards that guarantees a long shelf life, and ensures a high content of compounds with beneficial properties for health as well as a low content of nitrates. The quality of the product is influenced by numerous factors including the environment and cultivation techniques $[12,13]$ such as the supply of fertilizers and the application of substances that can act positively on the quality. The fertilizer element that plays the main role in the yield and quality is nitrogen, which, due to its high solubility in water, is also subjected to great attention in relation to the negative impact that its leaching determines on water bodies. The application rate influences the availability of the nutrient in the plant, some physiological processes, and the biosynthesis of some secondary compounds. Therefore, the management of nitrogen fertilization requires great attention both for the effects on the yield and quality, and on the environment, and must be aimed to maximize the resource use efficiency. Generally, high nitrogen rates have been used to improve crop yield. Nevertheless, nitrogen oversupply is not beneficial: it might result in a reduced yield, worsen some quality characteristics such as the nitrate content, reduce the nitrogen use efficiency (NUE) and water use efficiency (WUE), and increase diffuse source pollution. Conversely, nitrogen shortage is associated with a lower leaf chlorophyll content and lower yield [14]. Wild rocket can contain a high content of nitrates, being counted among the hyper-accumulating species of this anti-nutritional compound, which in humans, after various reactions, can lead to the formation of carcinogenic compounds such as nitrosamines [15]. Therefore, the Regulations of the European Commission (EU No 1258/2011) set the nitrate limits for the marketing of several leafy vegetables including rocket, whose maximum allowed values are equal to $7000 \mathrm{mg} \mathrm{kg}^{-1}$ in the period between October and March, and $6000 \mathrm{mg} \mathrm{kg}^{-1}$ during the remainder of the year [16].

The peculiar characteristics of this vegetable have favored the spreading of its cultivation even outside the area of origin in the Mediterranean, providing the opportunity for horticultural growers all over the world to have a new interesting cultivation option.

A strategy to improve the yield and quality is the use of substances showing biostimulating actions on some metabolic and physiological processes [17]. One of these substances of natural origin is strobilurin. Some of its structural variants (e.g., Pyraclostrobin, Azoxystrobin, Kresoxim-methyl) are marketed as broad-spectrum fungicides with non-toxic effects for humans and the environment and with positive complementary effects on the yield and quality of different crops [18-20].

These natural molecules are produced by a group of fungi belonging to the Basidiomycetes [e.g., Oudemansiella mucida (Schrad ex Fr) Hoehn and Strobilurus tenacellus (Pers ex Fr) Singer], agents of wood rot of some tree species [21,22]. 
In recent years, several studies have highlighted the possibility of exploiting the complementary properties of strobilurin-based agrochemicals, normally used for plant protection, to improve production and resources' use efficiency. In fact, after the application of these fungicides, several positive effects on plant physiology have been observed, such as an increase in the production of abscissic acid (ABA) and some enzymes involved in oxidative stress, such as superoxide dismutase (SOD), peroxidase (POD), catalase (CAT), and ascorbate peroxidase (APX) $[20,23,24]$, which can therefore improve gas exchange and WUE [25-27]. Positive effects on cell proliferation [28], nitrogen metabolism, and on the limitation of nitrate accumulation have been also highlighted. These effects are probably due to the stimulating action of nitrate reductase activity $[19,29,30]$, as observed following the application of Azoxystrobin on lettuce [31] and spinach baby leaf, on which an increase in chlorophyll, ascorbic acid, and total phenol content has been also observed [32].

In view of the growing economic importance of wild rocket, interest is rising in finding new solutions that are able to increase yield, improve quality, and enhance resource use efficiency. We hypothesized that the application of strobilurin-based products could help to achieve these goals. Currently, to the best of our knowledge, there is a lack of sufficient experimental evidence in the literature focused on the complementary effects of Azoxystrobin on wild rocket. Therefore, four crop cycles of wild rocket were carried out to verify the interactive effect of the Azoxystrobin and nitrogen rate on the main morphological parameters, yield, WUE, NUE, antioxidant activity, dry matter, chlorophyll, carotenoids, phenols, and nitrates.

\section{Material and Methods}

\subsection{Experimental Site Characteristics}

The research was carried out in the period of 5 November 2014-27 April 2015, in an unheated greenhouse covered with ethylene vinyl acetate (EVA, $200 \mu \mathrm{m}$ thick) film, located at 'Troyli' farm in the countryside of Policoro (MT), Southern Italy $\left(40^{\circ} 22^{\prime} \mathrm{N}, 16^{\circ} 62^{\prime} \mathrm{E} ; 150 \mathrm{~m}\right.$ a.s.l.).

The soil type is 'Typic Haploxeralfs fine loamy, mixed, superactive, thermic', according to the United States Department of Agriculture classification [33], over $100 \mathrm{~cm}$ deep and of good fertility. The climate is sub-humid, according to the De Martonne classification [34].

\subsection{Treatments, Experimental Design, and Crop Management}

The study focused on the combined effect of (i) two $\mathrm{N}$ levels (40 and $140 \mathrm{~kg} \mathrm{ha}^{-1}$, namely $\mathrm{N}_{40}$ and $\mathrm{N}_{140}$, respectively), and (ii) Azoxystrobin-based biostimulant (Azo+) $\left(\mathrm{Ortiva}^{\circledR}{ }^{\circledR}\right.$, Syngenta), besides a control without Azoxystrobin (Azo-).

Soil P-K fertilization was carried out before sowing. In particular, $100 \mathrm{~kg} \mathrm{ha}^{-1}$ of $\mathrm{P}_{2} \mathrm{O}_{5}$ (superphosphate) and $100 \mathrm{~kg} \mathrm{ha}^{-1}$ of $\mathrm{K}_{2} \mathrm{O}$ (potassium sulphate) were applied broadcaster, then buried with milling. The seedbed was prepared by arranging the soil in well-leveled 1.2-m wide raised beds. The sowing of the wild rocket was carried out on 5 November 2014, with a seeder in continuous rows $5 \mathrm{~cm}$ apart, using $0.7 \mathrm{~g} \mathrm{~m}^{-2}$ of seed. The emergence of $100 \%$ of the seedlings occurred four days after sowing with a density of about 1800 plants $\mathrm{m}^{-2}$. Four successive vegetative cycles were carried out by exploiting the 'regrowth' capacity of this species after harvesting.

Nitrogen, as ammonium nitrate, was applied broadcaster following the experimental plan. Particularly, the $\mathrm{N}$ doses (i.e., 40 and $140 \mathrm{~kg} \mathrm{ha}^{-1}$ ) were split into four applications: $40 \%$ before sowing, while the remaining part was divided into equal quantities and applied before each new crop cycle. Pest and disease management was carried out according to the Integrated Pest Management disciplinary of Basilicata Region [35]. Weed control was performed by combining the false sowing and hand weed removal.

Irrigation was scheduled by means of 'day-by-day' soil water balance, utilizing agrometeorological and soil hydrological data [36]. Crop evapotranspiration (ETc, $\mathrm{mm}$ ) was estimated following the standard FAO two-step procedure [37]: 


$$
\mathrm{ETc}=\mathrm{ETo} \times \mathrm{Kc}
$$

where

ETo $=$ reference evapotranspiration measured with the atmometer [38] (mm).

$\mathrm{Kc}=$ crop coefficient, whose values were selected according to the crop phenological stages [39].

Watering was carried out before the ready available water (RAW) in the soil layers most explored by roots was depleted. This threshold value $(p)$ throughout the whole crop cycles was assumed to be $45 \%$ of the available water (AW), as reported for other vegetables belonging to the Brassicaceae family [37]. The capillary rise and runoff were considered negligible for the high depth of the water table and for the low rainfall rate of the irrigation system, respectively. To make any corrections to the water balance estimated by the model, the water content of the soil in the root zone was measured every 10-11 days by the gravimetric method [40]. The irrigation method was a sprinkler with nozzles (30 $\mathrm{L} \mathrm{h}^{-1}, 3 \times 3-\mathrm{m}$ spaced) placed at the top of the greenhouse, which provided a rainfall intensity of about $3.3 \mathrm{~mm} \mathrm{~h}^{-1}$.

At the end of each crop cycle (19 December, 23 February, 24 March, and 27 April), the wild rocket was machine-harvested in a sampling area of $2 \mathrm{~m}^{2}$ for each sub-plot, by cutting the plants to $3 \mathrm{~cm}$ in height. After the collections, the "grooming" was carried out to prepare the crop for the next vegetative cycle. In particular, the crop residues (leaves cut but having escaped from the harvesting machine), were removed from the field by means of a suction machine to avoid the pollution of the product in subsequent collections.

In the Azo+ plots, Ortiva ${ }^{\circledR}\left(1 \mathrm{~L} \mathrm{ha}^{-1}, 0.15 \% v / v\right)$ was sprayed 12 days before collections with a backpack power sprayer (model MS073D, Maruyama Mfg. Co, Inc., Togane City, Japan); instead, in the control plots (Azo-), fresh water was applied with the same sprayer.

\subsection{Biomass, Yield, and Plant Biometric Characteristics}

For each collection, leaves and stems of the sampling area were used to determine the yield (total, marketable, and waste) and leaf area index (LAI). The latter parameter was assessed by measuring the area of a $200 \mathrm{~g}$ leaf sub-sample in triplicate, using an LAI meter (Li-COR, 3100, Lincoln, NE, USA). The value obtained was related to the leaf total weight of the sampling area $\left(2 \mathrm{~m}^{2}\right)$. The waste consisted of leaves that were yellowed, necrotic, or damaged by pathogens or pests. The aboveground biomass (AGB) was assessed at harvest by cutting the plants from the collar by means of a knife in a second sampling area of $0.2 \mathrm{~m}^{2}$, adjacent to the main sampling area in which the collection was carried out. About $50 \mathrm{~g}$ of AGB (in triplicate) were dried in a heat-ventilated oven at a temperature of $60^{\circ} \mathrm{C}$ to assess the dry matter percentage and compute the dry AGB (DAGB). Moreover, for each sub-plot, a sample of 10 plants randomly chosen was cut at collar to assess some biometric features: the mean weight, number of leaves per plant, leaf length and width, length of the leaf blade and leaf total length (leaf + petiole) ratio, and indentation index of the leaf margin. The latter parameter was assessed by attributing a score from 1 (slightly jagged margin) to 5 (very jagged margin).

\subsection{N Uptake, Nitrogen and Water Use Efficiency}

The $\mathrm{N}$ uptake $\left(\mathrm{N}_{\mathrm{up}}, \mathrm{g} \mathrm{m}^{-2}\right)$ was measured at each harvest. This parameter was obtained from the product between the dry mass of the yield $\left(\mathrm{YDM}, \mathrm{g} \mathrm{m}^{-2}\right)$ and the total nitrogen $(\mathrm{TN}, \%)$ contained therein.

NUE (g YDM g ${ }^{-1} \mathrm{~N}_{\text {up }}$ ), which represents the ability of the plant to transform nitrogen acquired from all sources into economic yield [41], was calculated according to Santamaria et al. [42]:

$$
\mathrm{NUE}=\mathrm{YDM} / \mathrm{N}_{\mathrm{up}}
$$

WUE was assessed for each crop cycle in view of three indicators, as follows [43]. 
The yield WUE (Y_WUE), which represents the ratio between the marketable yield $\left(\mathrm{Y}, \mathrm{kg} \mathrm{ha}^{-1}\right)$ and water lost by evapotranspiration $\left(\mathrm{ETc}, \mathrm{m}^{3} \mathrm{ha}^{-1}\right)$ :

$$
Y_{-} W U E=\frac{Y}{E T c}
$$

The biomass WUE (B_WUE), which represents the ratio between DAGB $\left(\mathrm{kg} \mathrm{ha}^{-1}\right)$ and ETc $\left(\mathrm{m}^{3} \mathrm{ha}^{-1}\right)$ :

$$
\mathrm{B} \_\mathrm{WUE}=\frac{\mathrm{DAGB}}{\mathrm{ETC}}
$$

The irrigation yield WUE (IY_WUE), which represents the ratio between $\mathrm{Y}\left(\mathrm{kg} \mathrm{ha}^{-1}\right)$ and the seasonal irrigation volume (IV, $\left.\mathrm{m}^{3} \mathrm{ha}^{-1}\right)$ :

$$
\text { IY_WUE }=\frac{Y}{I V}
$$

\subsection{Qualitative Features}

The following qualitative parameters were determined on the marketable wild rocket: leaf dry matter (DM), nitrates (Ni), total phenols (TP), total antioxidant activity (TAA), total carotenoids (TC), total chlorophyll $\left(\mathrm{Chl}_{\mathrm{a}}+\mathrm{Chl}_{\mathrm{b}}, \mathrm{Chl}_{\mathrm{a}+\mathrm{b}}\right)$, and total nitrogen $(\mathrm{TN})$.

$\mathrm{DM}$ - To asses leaf DM (g $100 \mathrm{~g}^{-1} \mathrm{FW}, \mathrm{FW}=$ fresh weight), about $50 \mathrm{~g}$ of marketable product in triplicate were used. After weighing, the plant material was placed in a heat-ventilated stove at $60^{\circ} \mathrm{C}$ until a constant weight was reached (about $48 \mathrm{~h}$ ).

$\mathrm{Ni}-$ About $10 \mathrm{~g}$ of dry marketable product were finely ground by means of a mill (IKA, Labortechnik, Staufen, Germany) equipped with a 1-mm sieve. The analyses were performed on a $0.5 \mathrm{~g}$ sub-sample in triplicate by ion chromatography (Dionex DX120; Dionex Corporation, Sunnyvale, CA, USA) with a conductivity detector, using an IonPack AG14 pre-column and an IonPack separation column AS14 [44]. The Ni concentration was assessed based on the sodium nitrate standard.

TP, TAA-About $20 \mathrm{~g}$ of fresh marketable product (in triplicate) were homogenized and subjected to extraction with methanol $(1: 5 w / v)$ under reflux on a water bath (two times for one hour). After filtering through a Whatman 1 filter paper, the methanolic extract was vacuumconcentrated and was then used for determining TP and TAA in triplicate. TP was assessed by spectrophotometer with the Folin-Ciocalteu method [45] and expressed as caffeic acid equivalent (CAE) $\left(\mathrm{mg} \mathrm{g}^{-1} \mathrm{DM}\right)$. TAA was assessed by means of the analysis of ABTS radical cations (2,2'-azino-bis-3ethylbenzothiazolin-6-sulphonic) [46] and expressed as Trolox ( $\mathrm{g}$ Trolox $100 \mathrm{~g}^{-1} \mathrm{DM}$ ).

$\mathrm{TC}, \mathrm{Chl}_{\mathrm{a}+\mathrm{b}}-\mathrm{About} 30 \mathrm{~g}$ of leaves were finely chopped in a mortar after adding liquid nitrogen and were then stored in the dark at $-20{ }^{\circ} \mathrm{C}$ until use. To carry out the pigment extraction, the plant material was homogenized with $80 \%$ acetone $\left(0.2 \mathrm{~g} \mathrm{~mL}^{-1}\right)$ in triplicate, and then centrifuged for $10 \mathrm{~min}$ at $14,000 \mathrm{rpm}$. On the recovered supernatant, three spectrophotometric readings (i.e., 662, 646, and $470 \mathrm{~nm}$ ) were performed. The absorbance (Abs) values obtained were then inserted in the following equations to obtain the concentrations of $\mathrm{Chl}_{\mathrm{a}}, \mathrm{Chl}_{\mathrm{b}}$, and TC [47]:

$$
\begin{gathered}
\mathrm{Chl}_{\mathrm{a}}\left(\mathrm{ug} \mathrm{mL}^{-1)}=12.21(\text { Abs } 662 \mathrm{~nm})-2.81(\text { Abs } 645 \mathrm{~nm})\right. \\
\mathrm{Chl}_{\mathrm{b}}\left(\mathrm{ug} \mathrm{mL}^{-1}\right)=20.13(\text { Abs } 645 \mathrm{~nm})-5.03(\text { Abs } 662 \mathrm{~nm}) \\
\text { TC }(\text { ug mL } \\
\text {-1 })=\left[1000(\text { Abs } 470 \mathrm{~nm})-3.270 \mathrm{Chl}_{\mathrm{a}}-104 \mathrm{Chl}_{\mathrm{b}}\right] / 198
\end{gathered}
$$

The method is based on the property of chlorophyll of absorbing light in the red area of the visible spectrum. All extraction procedures were performed in refrigerated and low-light conditions.

TN-The total nitrogen content of the collected rocket was obtained by the Kjeldahl method, using a sample of $1 \mathrm{~g}$ (in triplicate) of dried and finely ground vegetable material. 


\subsection{Statistical Analysis}

The experimental layout was a split-plot with three replications, where the $\mathrm{N}$ levels treatments occupied the plot and Azo (+/-) the sub-plot, $18 \mathrm{~m}^{2}$ in size. The data of each crop cycle were processed separately utilizing SPSS 17 software, according to a split-plot design, by analysis of variance (ANOVA). Mean values were separated by the Student-Newman-Keuls (SNK) test at $p=0.05$.

\section{Results}

\subsection{Evapotranspiration, Soil Water Regime, and Irrigation Supply}

As a consequence of the climatic trend, ETo was decreasing from $1.4 \mathrm{~mm} \mathrm{~d}^{-1}$ in the sowing period to about $0.5 \mathrm{~mm} \mathrm{~d}^{-1}$ at the end of January, and subsequently increased until reaching $1.5 \mathrm{~mm} \mathrm{~d}^{-1}$ at the end of the fourth crop cycle of wild rocket (Figure 1).

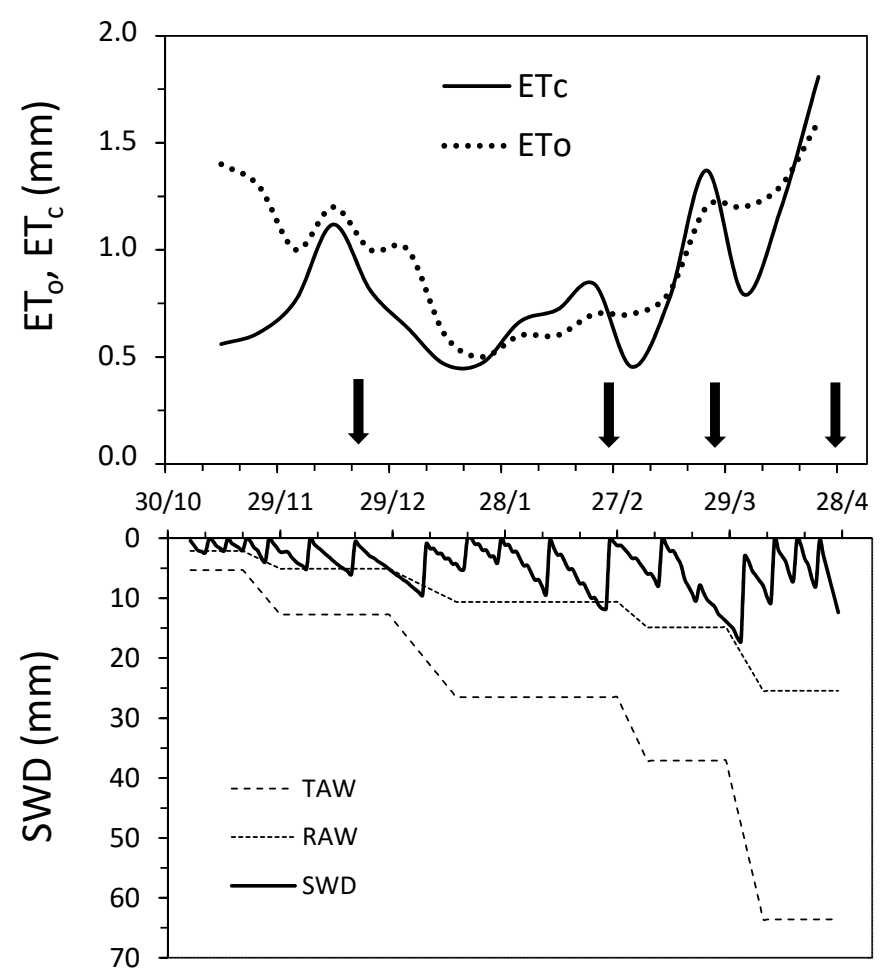

Figure 1. Trend of reference evapotranspiration (ETo), crop evapotranspiration (ETc), and soil water depletion (SWD) during the wild rocket crop cycles. TAW = Total Available Water, RAW = Ready Available Water. Arrows indicate collection dates.

The daily ETc during the crop cycles performed a sinusoidal trend as a consequence of the drastic changes in LAI and the canopy cover after collections, with a range of variation between 0.5 and $1.8 \mathrm{~mm}$ (Figure 1). The cumulative ETc for each crop cycle increased from $35.1 \mathrm{~mm}$ for the first crop cycle to $48.2 \mathrm{~mm}$ for the last one.

The soil water reserve has always been such as to ensure an optimal water supply to the crop, remaining above the RAW (Figure 1). The irrigation supply, referred to the individual crop cycles, increased from $308 \mathrm{~m}^{3} \mathrm{ha}^{-1}$ for the first crop cycle to $470 \mathrm{~m}^{3} \mathrm{ha}^{-1}$ for the last one, with an average of four watering applications.

\subsection{Yield and Quality Parameters}

The marketable yield of wild rocket showed an increasing trend from the first to the last collection, with average values between 1.15 and $1.74 \mathrm{~kg} \mathrm{~m}^{-2}$ (Table 1). The cumulated marketable yield of the four crop cycles, as an average of all treatments, was equal to $6.09 \mathrm{~kg} \mathrm{~m}^{-2}$. 
Table 1. Effects of the Azoxystrobin (Azo) application and N level (NL) on the yield and some morphological traits of wild rocket in the four crop cycles. Azo- = control without Azoxystrobin, Azo+ = with Azoxystrobin; $\mathrm{N}_{40}=40 \mathrm{~kg} \mathrm{ha}^{-1}$ of N, $\mathrm{N}_{140}=140 \mathrm{~kg} \mathrm{ha}^{-1}$ of N.

\begin{tabular}{|c|c|c|c|c|c|c|c|c|c|c|}
\hline \multirow{3}{*}{ Treatments } & \multirow{2}{*}{$\begin{array}{c}\text { Marketable } \\
\text { Yield }\end{array}$} & \multirow[b]{2}{*}{ LAI } & \multirow{2}{*}{$\begin{array}{c}\text { Plant Mean } \\
\text { Weight }\end{array}$} & \multicolumn{6}{|c|}{ Leaves } & \multirow{2}{*}{$\begin{array}{c}\text { Abovegrounc } \\
\text { Dry Biomass }\end{array}$} \\
\hline & & & & Number & $\begin{array}{c}\text { Total } \\
\text { Length (LT) }\end{array}$ & $\begin{array}{c}\text { Bade } \\
\text { Length (LB) }\end{array}$ & LB/LT & Width & $\begin{array}{l}\text { Incision } \\
\text { Index }\end{array}$ & \\
\hline & $\left(\mathrm{kg} \mathrm{m}^{-2}\right)$ & & $\left(\right.$ g plant $\left.^{-1}\right)$ & (n. plant ${ }^{-1}$ ) & $(\mathrm{cm})$ & $(\mathrm{cm})$ & $(\%)$ & (cm) & (score 1-5) & $\left(\mathrm{kg} \mathrm{m}^{-2}\right)$ \\
\hline & \multicolumn{10}{|c|}{ 1st crop cycle } \\
\hline $\begin{array}{l}\text { Azoxystrobin } \\
\text { (Azo) }\end{array}$ & ns & ns & ns & ns & ns & ns & ns & ns & ns & ns \\
\hline Azo- & 1.16 & 2.85 & 2.19 & 5.08 & 16.1 & 5.9 & 36.5 & 1.89 & 3.0 & 0.15 \\
\hline Azo+ & 1.13 & 2.72 & 2.03 & 4.97 & 16.2 & 5.8 & 35.8 & 1.88 & 2.9 & 0.16 \\
\hline N level (NL) & * & $*$ & ns & * & $*$ & $\mathrm{~ns}$ & ns & ns & ns & $*$ \\
\hline $\mathrm{N}_{40}$ & 1.05 & 2.48 & 2.09 & 4.80 & 15.9 & 5.8 & 36.8 & 1.90 & 3.0 & 0.14 \\
\hline $\mathrm{N}_{140}$ & 1.24 & 3.09 & 2.14 & 5.25 & 16.4 & 5.9 & 35.5 & 1.88 & 2.9 & 0.17 \\
\hline \multirow[t]{2}{*}{ Azo $\times$ NL } & ns & ns & ns & ns & ns & ns & ns & ns & ns & ns \\
\hline & \multicolumn{10}{|c|}{ 2nd crop cycle } \\
\hline $\begin{array}{c}\text { Azoxystrobin } \\
\text { (Azo) }\end{array}$ & * & * & * & * & * & * & ns & ns & ns & * \\
\hline Azo- & 1.48 & 2.12 & 3.68 & 9.3 & 17.4 & 9.0 & 51.5 & 1.08 & 4.7 & 0.23 \\
\hline $\mathrm{Azo}+$ & 1.63 & 2.60 & 3.95 & 9.9 & 19.6 & 10.0 & 50.9 & 1.07 & 4.7 & 0.25 \\
\hline N level (NL) & $*$ & $* *$ & $*$ & $*$ & ns & ns & ns & ns & $*$ & $*$ \\
\hline $\mathrm{N}_{40}$ & 1.47 & 2.18 & 3.60 & 9.2 & 18.7 & 9.7 & 51.6 & 1.06 & 4.9 & 0.24 \\
\hline $\mathrm{N}_{140}$ & 1.64 & 2.55 & 4.02 & 10.0 & 18.3 & 9.3 & 50.8 & 1.09 & 4.5 & 0.26 \\
\hline \multirow[t]{2}{*}{ Azo x NL } & ns & ns & ns & ns & ns & ns & ns & ns & ns & ns \\
\hline & \multicolumn{10}{|c|}{ 3rd crop cycle } \\
\hline $\begin{array}{l}\text { Azoxystrobin } \\
\text { (Azo) }\end{array}$ & * & * & * & ns & ns & ns & ns & ns & ns & * \\
\hline Azo- & 1.65 & 3.35 & 6.14 & 10.7 & 19.3 & 11.3 & 58.7 & 1.02 & 5.0 & 0.28 \\
\hline $\mathrm{Azo}+$ & 1.83 & 3.95 & 6.85 & 11.3 & 20.0 & 11.6 & 58.0 & 1.01 & 5.0 & 0.29 \\
\hline N level (NL) & $* *$ & $*$ & $* *$ & $*$ & ns & ns & $*$ & ns & ns & $*$ \\
\hline $\mathrm{N}_{40}$ & 1.61 & 3.30 & 5.79 & 10.2 & 19.8 & 11.2 & 56.7 & 1.04 & 5.0 & 0.28 \\
\hline $\mathrm{N}_{140}$ & 1.87 & 4.01 & 7.19 & 11.8 & 19.5 & 11.7 & 60.1 & 0.98 & 5.0 & 0.29 \\
\hline Azo $\times$ NL & ns & ns & ns & ns & ns & ns & ns & ns & ns & ns \\
\hline
\end{tabular}


Table 1. Cont.

\begin{tabular}{|c|c|c|c|c|c|c|c|c|c|c|}
\hline \multirow{3}{*}{ Treatments } & \multirow{2}{*}{$\begin{array}{c}\text { Marketable } \\
\text { Yield }\end{array}$} & \multirow[b]{2}{*}{ LAI } & \multirow{2}{*}{$\begin{array}{c}\text { Plant Mean } \\
\text { Weight }\end{array}$} & \multicolumn{6}{|c|}{ Leaves } & \multirow{2}{*}{$\begin{array}{l}\text { Aboveground } \\
\text { Dry Biomass }\end{array}$} \\
\hline & & & & Number & $\begin{array}{c}\text { Total } \\
\text { Length (LT) }\end{array}$ & $\begin{array}{c}\text { Bade } \\
\text { Length (LB) }\end{array}$ & LB/LT & Width & $\begin{array}{l}\text { Incision } \\
\text { Index }\end{array}$ & \\
\hline & $\left(\mathrm{kg} \mathrm{m}^{-2}\right)$ & & (g plant $\left.^{-1}\right)$ & (n. plant ${ }^{-1}$ ) & $(\mathrm{cm})$ & $(\mathrm{cm})$ & $(\%)$ & $(\mathrm{cm})$ & (score 1-5) & $\left(\mathrm{kg} \mathrm{m}^{-2}\right)$ \\
\hline & \multicolumn{10}{|c|}{ 4th crop cycle } \\
\hline $\begin{array}{l}\text { Azoxystrobin } \\
\text { (Azo) }\end{array}$ & * & * & * & ns & ns & ns & ns & ns & ns & * \\
\hline Azo- & 1.50 & 3.06 & 7.62 & 14.8 & 23.4 & 12.2 & 52.7 & 1.33 & 5.0 & 0.37 \\
\hline $\mathrm{Azo}+$ & 1.81 & 3.57 & 8.34 & 16.2 & 20.7 & 10.0 & 48.7 & 1.10 & 5.0 & 0.41 \\
\hline N level (NL) & $*$ & $*$ & $* *$ & $*$ & ns & ns & ns & ns & ns & $*$ \\
\hline $\mathrm{N}_{40}$ & 1.52 & 3.03 & 7.15 & 14.2 & 20.8 & 11.0 & 53.0 & 1.24 & 5.0 & 0.37 \\
\hline $\mathrm{N}_{140}$ & 1.80 & 3.59 & 8.80 & 16.8 & 23.2 & 11.2 & 48.5 & 1.19 & 5.0 & 0.41 \\
\hline Azo $\times$ NL & ns & ns & ns & ns & ns & ns & ns & $\mathrm{ns}$ & ns & ns \\
\hline
\end{tabular}


A positive effect of the higher nitrogen amount on the yield was noticed. In fact, this parameter in $\mathrm{N}_{140}$ was on average about $16 \%$ higher than in $\mathrm{N}_{40}$. The increase in the yield was accompanied by a rise in related parameters, such as the LAI, the average plant weight, the morphology of the leaves, and, in particular, the number of leaves.

The application of Azoxystrobin did not affect the yield in the first collection, while in the subsequent ones it resulted in an increasing growth, from $10.1 \%$ to $20.6 \%$ in the last one (Table 1 ). The differences in the yield compared to the control were caused by a corresponding variation of the main biometric parameters.

A higher $\mathrm{N}$ supply resulted in a reduction in the percentage of leaf dry matter in the third harvest, while the application of Azoxystrobin did not affect this parameter (Table 2). By increasing the $\mathrm{N}$ supply, the chlorophyll rose in the first two collections, while it decreased in the subsequent ones; the carotenoid content, on the other hand, decreased in all collections, on average by $11.5 \%$. With the application of Azoxystrobin, chlorophyll and carotenoids increased in all collections, on average by 15.2 and $9.7 \%$, respectively (Table 2).

The increase in the $\mathrm{N}$ supply reduced the content of total phenols and the antioxidant activity by 10.1 and $26.1 \%$ on average, respectively. On the contrary, by applying Azoxystrobin, an increase of 9.4 and $17.4 \%$, respectively, was found in these last two parameters (Table 2).

The effect of the $\mathrm{N}$ level on the nitrate content was not very highlighted. In fact, a significant increase with the higher $\mathrm{N}$ dose was observed only in the first $(+11.5 \%)$ and third collections $(+24.7 \%)$. The nitrate content did not significantly change after Azoxystrobin application (Table 2).

\subsection{N Uptake, NUE, and WUE}

Among the crop cycles, as the average of all treatments, $\mathrm{N}_{\text {up }}$ ranged from 3.5 to $6.4 \mathrm{~g} \mathrm{~m}^{-2}$, and NUE ranged from 24.3 to $24.8 \mathrm{~g} \mathrm{YDM} \mathrm{g}^{-1} \mathrm{~N}_{\mathrm{up}}$ (Figure 2). With the exception of the first crop cycle (which did not show differences between nitrogen rates), in others crop cycles the $\mathrm{N}_{\text {up }}$ and NUE values were lower $(-23.4 \%)$ and higher $(+14.4 \%)$, respectively, for the $\mathrm{N}_{40}$ treatment with respect to the $\mathrm{N}_{140}$ one (Figure 2). The $\mathrm{N}_{\text {up }}$ response in relation to the Azo treatments did not show differences in the first and third crop cycles, and instead resulted in being higher by $8.0 \%$, on average, in Azo+ at the second and fourth crop cycles. NUE did not change after the application of Azoxystrobin in the first two collections, and instead it improved on average by $10.5 \%$ in the last two (Figure 2). No significant interaction occurred between the Azo and $\mathrm{N}$ levels for $\mathrm{N}_{\text {up }}$ and NUE.

The increase in the $\mathrm{N}$ level favored a greater WUE. In fact, on average there was an increase by $15.8,7.3$, and $16.1 \%$ in the Y_WUE, B_WUE, and IY_WUE, respectively (Table 3). The application of Azoxystrobin did not affect the three WUE indicators in the first collection. On the other hand, between the second and the last collection, Azo+ enhanced the three parameters: the average increase was 13.9, 9.1, and $13.8 \%$ for Y_WUE, B_WUE, and IY_WUE, respectively (Table 3). 
Table 2. Effects of the Azoxystrobin (Azo) application and N level (NL) on leaf dry matter (DM), nitrate (Ni), total phenols (TP), total antioxidant activity (TAA), total chlorophyll $\left(\mathrm{Chl}_{\mathrm{a}+\mathrm{b}}\right)$, and total carotenoids (TC) of wild rocket in the four crop cycles. Azo $-=$ control without Azoxystrobin, Azo $+=$ with Azoxystrobin; $\mathrm{N}_{40}=$ $40 \mathrm{~kg} \mathrm{ha}^{-1}$ of $\mathrm{N}, \mathrm{N}_{140}=140 \mathrm{~kg} \mathrm{ha}^{-1}$ of $\mathrm{N}$.

\begin{tabular}{|c|c|c|c|c|c|c|}
\hline \multirow{2}{*}{ Treatments } & DM & $\mathbf{N i}$ & TP & TAA & $\mathrm{Chl}_{\mathrm{a}+\mathrm{b}}$ & TC \\
\hline & $\left(\mathrm{g} 100 \mathrm{~g}^{-1} \mathrm{FW}\right)$ & $\left(\mathrm{mg} \mathrm{kg}^{-1} \mathrm{FW}\right)$ & $\left(\mathrm{mg} \mathrm{CAE} \mathrm{g}^{-1} \mathrm{DM}\right)$ & (g Trolox $\left.100 \mathrm{~g}^{-1} \mathrm{DM}\right)$ & $\left(\mu \mathrm{g} \mathrm{g}^{-1} \mathrm{DM}\right)$ & $\left(\mu \mathrm{g} \mathrm{g}^{-1} \mathrm{DM}\right)$ \\
\hline & \multicolumn{6}{|c|}{ 1st crop cycle } \\
\hline Azoxystrobin (Azo) & ns & ns & ns & $*$ & ns & * \\
\hline Azo- & 7.2 & 4838.5 & 11.7 & 0.37 & 836.9 & 155.5 \\
\hline $\mathrm{AzO}+$ & 7.4 & 4536.2 & 12.6 & 0.45 & 887.0 & 164.8 \\
\hline N level (NL) & ns & $*$ & $*$ & $*$ & $*$ & $*$ \\
\hline $\mathrm{N}_{40}$ & 7.2 & 4432.9 & 13.2 & 0.48 & 787.5 & 170.1 \\
\hline $\mathrm{N}_{140}$ & 7.4 & 4942.0 & 11.1 & 0.34 & 936.4 & 150.2 \\
\hline \multirow[t]{2}{*}{ Azo $\times$ NL } & ns & ns & ns & ns & ns & ns \\
\hline & \multicolumn{6}{|c|}{ 2nd crop cycle } \\
\hline Azoxystrobin (Azo) & ns & ns & ns & ns & $*$ & $* *$ \\
\hline Azo- & 8.5 & 4334.7 & 13.6 & 0.44 & 790.7 & 149.8 \\
\hline Azo+ & 8.7 & 4438.1 & 13.8 & 0.47 & 966.7 & 173.1 \\
\hline N level (NL) & ns & ns & $*$ & $*$ & $*$ & $* *$ \\
\hline $\mathrm{N}_{40}$ & 8.6 & 4398.0 & 14.5 & 0.50 & 825.6 & 175.2 \\
\hline $\mathrm{N}_{140}$ & 8.6 & 4374.4 & 12.9 & 0.41 & 931.8 & 147.7 \\
\hline \multirow[t]{2}{*}{ Azo x NL } & ns & ns & ns & ns & ns & ns \\
\hline & \multicolumn{6}{|c|}{ 3rd crop cycle } \\
\hline Azoxystrobin (Azo) & ns & ns & $*$ & $*$ & $*$ & $*$ \\
\hline Azo- & 8.2 & 3265.5 & 13.6 & 0.42 & 835.4 & 169.7 \\
\hline $\mathrm{Azo}+$ & 8.1 & 2946.8 & 14.6 & 0.52 & 948.1 & 187.9 \\
\hline N level (NL) & $*$ & $*$ & $\mathrm{~ns}$ & $*$ & $*$ & $*$ \\
\hline $\mathrm{N}_{40}$ & 8.5 & 2764.2 & 14.4 & 0.53 & 936.6 & 185.4 \\
\hline $\mathrm{N}_{140}$ & 7.9 & 3448.3 & 13.8 & 0.41 & 846.9 & 172.2 \\
\hline Azo x NL & ns & ns & ns & ns & ns & ns \\
\hline
\end{tabular}


Table 2. Cont

\begin{tabular}{|c|c|c|c|c|c|c|}
\hline \multirow{3}{*}{ Treatments } & DM & $\mathrm{Ni}$ & TP & TAA & $\mathrm{Chl}_{\mathrm{a}+\mathrm{b}}$ & TC \\
\hline & $\left(\mathrm{g} 100 \mathrm{~g}^{-1} \mathrm{FW}\right)$ & $\left(\mathrm{mg} \mathrm{kg}^{-1} \mathrm{FW}\right)$ & $\left(\mathrm{mg} \mathrm{CAE} \mathrm{g}^{-1} \mathrm{DM}\right)$ & (g Trolox $\left.100 \mathrm{~g}^{-1} \mathrm{DM}\right)$ & $\left(\mu g^{-1} \mathrm{DM}\right)$ & $\left(\mu \mathrm{g} \mathrm{g}^{-1} \mathrm{DM}\right)$ \\
\hline & \multicolumn{6}{|c|}{ 4rt crop cycle } \\
\hline Azoxystrobin (Azo) & ns & ns & $* *$ & $* *$ & $*$ & $*$ \\
\hline Azo- & 9.4 & 2017.0 & 14.8 & 0.57 & 651.5 & 189.7 \\
\hline $\mathrm{Azo}+$ & 9.7 & 1959.5 & 17.9 & 0.67 & 774.2 & 201.4 \\
\hline N level (NL) & ns & ns & $*$ & $* *$ & $* *$ & $* *$ \\
\hline $\mathrm{N}_{40}$ & 9.6 & 1996.0 & 17.1 & 0.75 & 787.9 & 207.5 \\
\hline $\mathrm{N}_{140}$ & 9.5 & 1980.6 & 15.5 & 0.49 & 637.8 & 183.6 \\
\hline Azo $\times$ NL & ns & ns & ns & ns & ns & ns \\
\hline
\end{tabular}

$\mathrm{ns},{ }^{*}, * *$ indicate $\mathrm{F}$ test not significant or significant at $P<0.05$ and $P<0.01$, respectively.

Table 3. Effects of the Azoxystrobin (Azo) application and $\mathrm{N}$ level (NL) on: (i) the yield (Y_WUE, $\mathrm{kg} \mathrm{m}^{-3}$ ) and biomass (B_WUE, $\mathrm{kg}^{-3}$ ) water use efficiency, and (ii) the irrigation yield water use efficiency (IY_WUE, $\mathrm{kg} \mathrm{m}^{-3}$ ) of wild rocket in the four crop cycles. Azo- = control without Azoxystrobin, Azo+ = with Azoxystrobin; $\mathrm{N}_{40}=40 \mathrm{~kg} \mathrm{ha}^{-1}$ of N, $\mathrm{N}_{140}=140 \mathrm{~kg} \mathrm{ha}^{-1}$ of $\mathrm{N}$.

\begin{tabular}{|c|c|c|c|c|c|c|c|c|c|c|c|c|}
\hline \multirow{2}{*}{ Treatments } & \multicolumn{3}{|c|}{ 1st Crop Cycle } & \multicolumn{3}{|c|}{ 2nd Crop Cycle } & \multicolumn{3}{|c|}{ 3rd Crop Cycle } & \multicolumn{3}{|c|}{ 4rt Crop Cycle } \\
\hline & Y_WUE & B_WUE & IY_WUE & Y_WUE & B_WUE & IY_WUE & Y_WUE & B_WUE & IY_WUE & Y_WUE & B_WUE & IY_WUE \\
\hline $\begin{array}{c}\text { Azoxystrobin } \\
\text { (Azo) }\end{array}$ & ns & ns & ns & * & ns & * & * & ns & * & $* *$ & * & $* *$ \\
\hline Azo- & 33.1 & 4.3 & 37.7 & 35.1 & 5.5 & 35.3 & 36.9 & 6.2 & 36.9 & 31.2 & 7.6 & 31.5 \\
\hline Azo+ & 32.3 & 4.4 & 36.8 & 38.6 & 6.0 & 38.7 & 41.0 & 6.6 & 41.0 & 37.6 & 8.5 & 38.0 \\
\hline N level (NL) & $* *$ & $*$ & $* *$ & $*$ & ns & $*$ & $* *$ & ns & $* *$ & * & ns & $*$ \\
\hline $\mathrm{N}_{40}$ & 30.0 & 4.1 & 34.1 & 34.9 & 5.6 & 35.0 & 36.1 & 6.4 & 36.1 & 31.5 & 7.7 & 31.8 \\
\hline $\mathrm{N}_{140}$ & 35.4 & 4.7 & 40.4 & 38.8 & 5.9 & 39.0 & 41.8 & 6.4 & 41.8 & 37.3 & 8.4 & 37.7 \\
\hline Azo $\times$ NL & ns & ns & ns & ns & ns & ns & ns & ns & ns & ns & ns & ns \\
\hline
\end{tabular}

$\mathrm{ns},{ }^{*}, * *$ indicate $\mathrm{F}$ test not significant or significant at $P<0.05$ and $P<0.01$, respectively. 
(A)
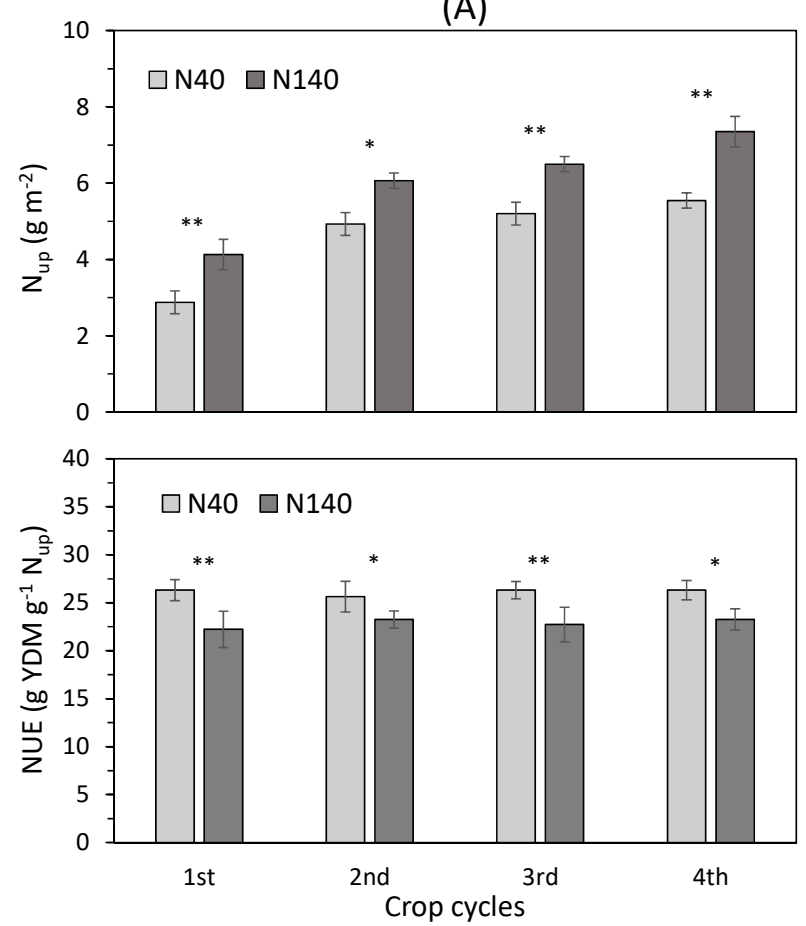

(B)
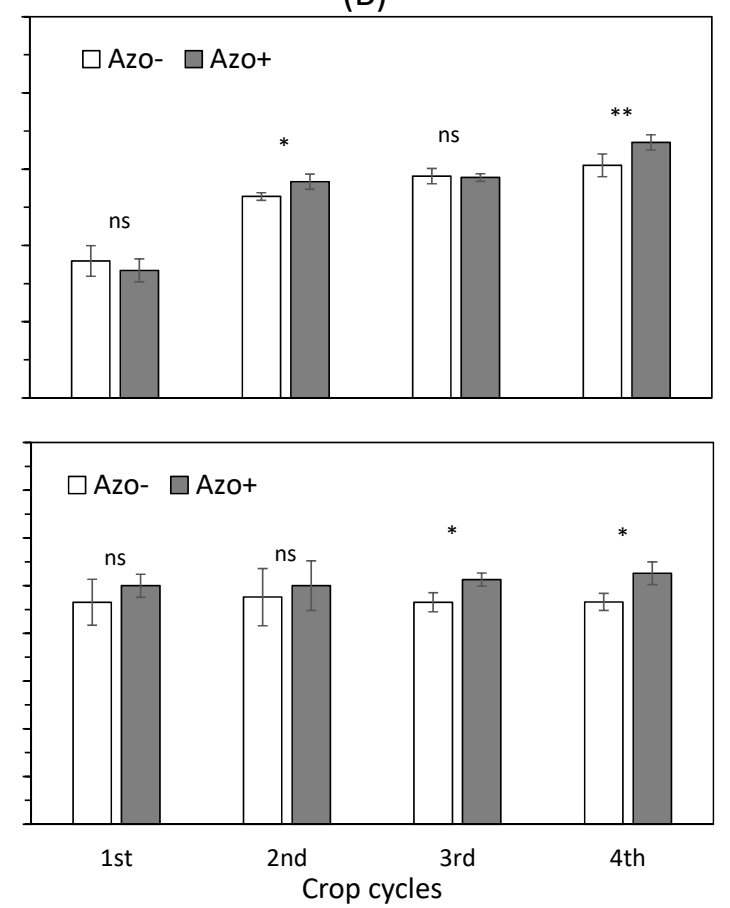

Figure 2. Effects of the (A) $\mathrm{N}$ level and (B) Azoxystrobin on the $\mathrm{N}$ uptake $\left(\mathrm{N}_{\mathrm{up}}, \mathrm{g} \mathrm{m}^{-2}\right)$ and nitrogen use efficiency (NUE, $\mathrm{g}$ YDM g ${ }^{-1} \mathrm{~N}_{\mathrm{up}}$ ) of wild rocket in the four crop cycles. YDM = yield dry matter; Azo- $=$ control without Azoxystrobin, Azo+ = with Azoxystrobin; $\mathrm{N}_{40}=40 \mathrm{~kg} \mathrm{ha}^{-1}$ of $\mathrm{N}, \mathrm{N}_{140}=$ $140 \mathrm{~kg} \mathrm{ha}^{-1}$ of $\mathrm{N}$. Vertical bars indicate SD $(n=6) . \mathrm{ns},{ }^{*},{ }^{* *}$ indicate $\mathrm{F}$ test not significant or significant at $p \leq 0.05$ and $p \leq 0.01$, respectively.

\section{Discussion}

\subsection{Yield and Qualitative Parameters}

The yield of wild rocket obtained in the various collections was very similar to that obtained in the same location and in the same period by Schiattone et al. [48], but considerably higher than the one indicated by Pimpini et al. [49] for Southern Italy. Similar yields are reported for different environments and cultivation periods [50,51]. An increase between the yield obtained in winter and that of the hottest periods is reported by Hall et al. [51]. The main factor that can influence the ability for wild rocket to regrow is attributable to environmental conditions. This justifies the contrasting results between the trend of an increase of the yield in the four crop cycles of our trial and the data obtained by other authors [52,53]. The latter, in fact, report that the yield decreased after the first harvest but that this occurred with a spring-summer cycle. The results of our research show that, in Southern Italy, wild rocket is well suited to multiple crop cycles, especially in the autumn-spring period.

The highest $\mathrm{N}$ dose, as already observed by Schiattone et al. [48], led to a significant increase in the yield, mainly due to the increase in the number of leaves and, secondarily, their size. This result agrees with findings on other leafy vegetables [54-56].

The use of Azoxystrobin led to a significant increase in the yield. In addition to the normal fungicidal activity, a biostimulating action of this substance has also been observed in the literature. For example, a positive action of strobilurins on cell proliferation has been demonstrated, which then leads to an increase in plant growth, linked to iron, nitrates, and sugar transport [28]. Other authors have attributed an enhancement in the yield to an increase in chlorophyll $[19,23,31,32]$, in turn caused by the increase in cytokinins involved in its biosynthesis $[29,57]$ and by the reduction of ethylene [58], a phytohormone known to be involved in the processes of senescence and the degradation of chlorophyll [59]. On the other hand, the results obtained in our trial confirm the positive 
effect of Azoxystrobin on the chlorophyll content of wild rocket. In addition, the positive effect of Azoxystrobin has already been highlighted, both on chlorophyll biosynthesis $[27,60,61]$ and on slowing down its degradation ('green effect') [23,29]. The improvement in chlorophyll biosynthesis promoted by strobilurins also involves an increase in nitrate reductase (NR) activity [60], which, by improving the $\mathrm{N}$ metabolism [62], would increase $\mathrm{N}$ availability for plants and would also, therefore, favor the formation of chlorophyll, being its main constituent [63].

Leaf total carotenoids decreased with an increase in the $\mathrm{N}$ supply, while the effect of the $\mathrm{N}$ level on the chlorophyll content was variable in the various collections. Conflicting results are reported in the literature about the effects of $\mathrm{N}$ availability on these parameters. Kopsell et al. [64] reported that the increase in the $\mathrm{N}$ level did not affect chlorophyll and carotenoids in the fresh tissues of cabbage leaves, but for the latter parameter the trend was reversed if the value was expressed on the basis of dry matter. However, other authors [31,32] reported a significant increase in the chlorophyll content in lettuce and spinach leaves by increasing the $\mathrm{N}$ dose, as would be expected, $\mathrm{N}$ being one of the main constituents of chlorophyll [65]. The phenol content and antioxidant activity decreased when increasing the $\mathrm{N}$ amount, as was also observed by other authors [66,67].

Azoxystrobin favored the increase in phenol content and antioxidant activity, parameters notoriously closely related. Following the application of Azoxystrobin, Conversa et al. [32] observed an increase in phenol content on baby leaf spinach, while Bonasia et al. [31] did not observe any effects on lettuce.

In general, the nitrate content of the leaves has always been below the limits imposed by European legislation for wild rocket [68], as also observed by Bonasia et al. [69] in Southern Italy. The decreasing trend, between the first and last collection, of the value of this anti-nutritional compound probably occurred due to the progressive increase in solar radiation and air temperature between December (first collection) and April (last collection), factors that notoriously interact with the activation of NR and, therefore, with the metabolism of nitrogen in the plant [69-71]. Results that are in agreement have been observed on lettuce and spinach grown in Southern Italy [31,32], where, as in our case, the environmental conditions are favorable for a fast metabolization of $\mathrm{N}$ absorbed by the plant.

The increase in the $\mathrm{N}$ level favored a greater $\mathrm{Ni}$ accumulation in the leaves of wild rocket, consistent with data found in the literature, since the higher content of $\mathrm{N}$ in the rhizosphere would favor its absorption by the roots and, therefore, the accumulation of $\mathrm{Ni}$ in the aerial part [71-73]. The application of Azoxystrobin slightly reduced the $\mathrm{Ni}$ in the leaves of wild rocket. These changes were limited compared to expectations, in view of the experimental findings that attribute to Azoxystrobin the capacity to stimulate NR activity [30-32,60]. This probably occurred because of the favorable climatic conditions that contributed to a fast $\mathrm{N}$ metabolization in all treatments.

\subsection{N Uptake, NUE and WUE}

$\mathrm{N}_{\text {up }}$ increased with a greater soil $\mathrm{N}$ availability and the corresponding increase in the yield, as observed on numerous species including wild rocket $[48,74,75]$. The NUE, on the other hand, was higher with the lowest nitrogen rate, as previously reported on wild rocket $[42,48]$ as well as on other species [76].

The application of Azoxystrobin resulted in a moderate increase in $\mathrm{N}_{\mathrm{up}}$ as a consequence of the increase in yield that this compound would have determined. In addition, the trend towards an increase in the NUE was also observed, demonstrating the positive effects of this compound on $\mathrm{N}$ metabolism, cell proliferation, and growth processes $[18,28]$.

According to the observations of other authors $[39,48]$, this research confirms that wild rocket, along with other leaf vegetables (i.e., lettuce and celery) [77] with high harvest index values, has a high WUE, particularly the Y_WUE.

The difference in photosynthetic metabolism could be one of the factors probably contributing to the high Y_WUE of this species compared to other leaf vegetables. In fact, $D$. tenuifolia belongs to 
species with an intermediate carbon cycle $\left(\mathrm{C}_{3}-\mathrm{C}_{4}\right)$, known for its high photosynthetic efficiency [78], which would contribute to a greater biomass production for each unit of evapotranspired water.

In our trial, it was observed that the general trend of the three WUE parameters was better at a higher $\mathrm{N}$ level, as already observed by Schiattone et al. [48]. Several studies have shown that the N supply improves the WUE [56], even if it has been observed that the WUE increases up to certain $\mathrm{N}$ levels while it decreases with excessive $\mathrm{N}$ doses [79].

Azoxystrobin also improved the WUE, in accordance with the findings of other authors on tomatoes $[19,25,26,80]$. This result is the direct consequence of the positive effect of Azoxystrobin on biomass production and yield. Furthermore, the possible effect of this compound on the reduction of transpiration cannot be overlooked $[60,81]$, as it seems that it can also act on the control of the stomatal conductance through the stimulation of ABA biosynthesis, a hormone known to be involved in regulating the stomatal opening [20].

\section{Conclusions}

The effect of Azoxystrobin was assessed in research carried out in Southern Italy on four crop cycles of wild rocket under two nitrogen rates.

The findings show that Azoxystrobin, through its complementary effects on the physiology and metabolism already reported in the literature for different species, can contribute to increasing the yield, improving the water and nitrogen use efficiency, and enhancing some qualitative features (i.e., phenols, chlorophyll, carotenoids, and antioxidant activity) of wild rocket, regardless of the nitrogen level. Therefore, considering that Azoxystrobin is a fungicide that is also very effective for the control of some diseases of wild rocket [82], its introduction in the phytosanitary defense plan of this species should be promoted.

Contrary to expectations, Azoxystrobin did not cause significant reductions in the nitrate content, probably due to the environmental conditions which, in any case, contributed to keep the level of this anti-nutritional compound well below the limits imposed by European regulations.

Therefore, further research is desirable, possibly into growing conditions that may favor the accumulation of nitrates in the plant (e.g., low solar radiation, excess nitrogen), so as to better evaluate the possible effects of Azoxystrobin on this important qualitative feature of wild rocket.

Author Contributions: Conceptualization, methodology, and data analysis, V.C. (Vincenzo Candido), V.C. (Vito Cantore), D.C., M.P. and M.I.S.; experimental measurements, V.C. (Vincenzo Candido), F.B., V.C. (Vito Cantore), D.C., D.D.V., L.S., R.V., and M.I.S.; writing-Original draft preparation, V.C. (Vincenzo Candido), V.C. (Vito Cantore) and M.I.S.; writing-Review and editing, V.C. (Vincenzo Candido), F.B., V.C. (Vito Cantore), D.C., D.D.V., L.S. and M.I.S.; supervision and project administration, V.C. (Vincenzo Candido) and M.P. All authors have read and agreed to the published version of the manuscript.

Funding: This research was supported by Research Project PIFOL_Production Chain Integrated Project (PIF-Territorial productive sector the fruit and vegetable, Basilicata. PSR Basilicata Region 2007-2013. Misura 124, founded by Basilicata Region.

Acknowledgments: The authors wish to thank Paolo Putignano for technical support and Rocco De Ruggieri for having made available the experimental field and equipment of his farm.

Conflicts of Interest: The authors declare no conflict of interest.

\section{References}

1. Nicoletti, R.; Raimo, F.; Miccio, G. Diplotaxis tenuifolia: Biology, production and properties. Eur. J. Plant Sci. Biotechnol. 2007, 1, 36-43.

2. Caruso, G.; Stoleru, V.; De Pascale, S.; Cozzolino, E.; Pannico, A.; Giordano, M.; Teliban, G.; Cuciniello, A.; Rouphael, Y. Production, leaf quality and antioxidants of perennial wall rocket as affected by crop cycle and mulching type. Agronomy 2019, 9, 194. [CrossRef]

3. Caruso, G.; Parrella, G.; Giorgini, M.; Nicoletti, R. Crop systems, quality and protection of Diplotaxis tenuifolia. Agriculture 2018, 8, 55. [CrossRef] 
4. Schiattone, M.I.; Candido, V.; Cantore, V.; Montesano, F.F.; Boari, F. Water use and crop performance of two wild rocket genotypes under salinity conditions. Agric. Water Manag. 2017, 194, 214-221. [CrossRef]

5. Erice, G.; Sanz-Sáez, A.; Aranjuelo, I.; Irigoyen, J.J.; Aguirreolea, J.; Avice, J.-C.; Sánchez-Díaz, M. Photosynthesis, $\mathrm{N}_{2}$ fixation and taproot reserves during the cutting regrowth cycle of alfalfa under elevated $\mathrm{CO}_{2}$ and temperature. J. Plant Physiol. 2011, 168, 2007-2014. [CrossRef]

6. Schiattone, M.I. Interventi Agronomici per Migliorare la Produzione, la Qualità e L'efficienza d'uso Dell'acqua e dell'azoto Della Ruchetta [Diplotaxis tenuiflia (L.) DC.]. [Agronomic Interventions to Improve Yield, Quality and Water and Nitrogen use Efficiency of Rocket (Diplotaxis tenuiflia L. DC.)]. Ph.D. Tesis, Università degli Studi della Basilicata, Potenza, Italy, 2018; 191p.

7. Cavaiuolo, M.; Ferrante, A. Nitrates and glucosinolates as strong determinants of the nutritional quality in rocket leafy salads. Nutrients 2014, 6, 1519-1538. [CrossRef]

8. D'Antuono, L.F.; Elementi, S.; Neri, R. Exploring new potential health promoting vegetables: Glucosinolates and sensory attributes of rocket salads and related Diplotaxis and Eruca species. J. Sci. Food Agric. 2009, 89, 713-722. [CrossRef]

9. Di Venere, D.; Calabrese, N.; Linsalata, V.; Cardinali, A.; Bianco, V.V. Influence of sowing time on phenolic composition of rocket. Acta Hortic. 2000, 533, 343-350. [CrossRef]

10. Ramos-Bueno, R.P.; Rincón-Cervera, M.A.; González-Fernández, M.J.; Guil-Guerrero, J.L. Phytochemical composition and antitumor activities of new salad greens: Rucola (Diplotaxis tenuifolia) and corn salad (Valerianella locusta). Plant Foods Hum. Nutr. 2016, 71, 197-203. [CrossRef]

11. Koukounaras, A.; Bantis, F.; Karatolos, N.; Melissas, C.; Vezyroglou, A. Influence of pre-harvest factors on postharvest quality of fresh-cut and baby leafy vegetables. Agronomy 2020, 10, 172. [CrossRef]

12. Colelli, G.; Elia, A. I prodotti ortofrutticoli di IV gamma: Aspetti fisiologici e tecnologici. [Physiological and technological aspects of fresh-cut horticultural products]. Italus Hortus 2009, 16, 55-78.

13. Kader, A.A. Flavour quality of fruits and vegetables. J. Sci. Food Agric. 2008, 88, 1863-1868. [CrossRef]

14. Mahlangu, R.I.S.; Maboko, M.M.; Mudau, F.N. Growth, yield and mineral content of basil and cultivated rocket due to plant density and nitrogen level. Int. J. Veget. Sci. 2019, 25, 1-15. [CrossRef]

15. Habermeyer, M.; Roth, A.; Guth, S.; Diel, P.; Engel, K.-H.; Epe, B.; Fürst, P.; Heinz, V.; Humpf, H.-U.; Joost, H.-G.; et al. Nitrate and nitrite in the diet: How to assess their benefit and risk for human health. Mol. Nutr. Food Res. 2015, 59, 106-128. [CrossRef]

16. Franzoni, G.; Cocetta, G.; Trivellini, A.; Ferrante, A. Transcriptional regulation in rocket leaves as affected by salinity. Plants 2020, 9, 20. [CrossRef]

17. Du Jardin, P. Plant biostimulants: Definition, concept, main categories and regulation. Sci. Hortic. 2015, 196, 3-14. [CrossRef]

18. Amaro, A.C.E.; Baron, D.; Ono, E.O.; Rodrigues, J.D. Physiological effects of strobilurin and carboxamides on plants: An overview. Acta Physiol. Plant. 2020, 42, 4. [CrossRef]

19. Boari, F.; Cantore, V.; Di Venere, D.; Sergio, L.; Candido, V.; Schiattone, M.I. Pyraclostrobin can mitigate salinity stress in tomato crop. Agric. Water Manag. 2019, 222, 254-264. [CrossRef]

20. Venancio, W.S.; Tavares Rodrigues, M.A.; Begliomini, E.; de Souza, N.L. Physiological effects of strobilurin fungicides on plants. UEPG Ciência Exatas E Terra Ciênc. Agrar. E Eng. Ponta Grossa.

21. Bartlett, D.W.; Clough, J.M.; Godwin, J.R.; Hall, A.A.; Hamer, M.; Parr-Dobrzanski, B. Review: The strobilurin fungicides. Pest Manag. Sci. 2002, 58, 649-662. [CrossRef]

22. Balba, H. Review of strobilurin fungicide chemicals. J. Environ. Sci. Health Part B 2007, 42, 441-451. [CrossRef] [PubMed]

23. Liang, S.; Xu, X.; Lu, Z. Effect of Azoxystrobin fungicide on the physiological and biochemical indices and ginsenoside contents of ginseng leaves. J. Ginseng Res. 2018, 42, 175-182. [CrossRef] [PubMed]

24. Lopes, A.M.; Schumacher, P.V.; Martínez, A.T.P.; da Costa Netto, A.P.; Chalfun-Junior, A. Insights into the positive effect of Pyraclostrobin on sugarcane productivity. Agronomy 2018, 8, 122. [CrossRef]

25. Boari, F.; Todorovic, M.; Albrizio, R.; Sellami, M.H.; Schiattone, M.I.; Cantore, V. Le strobilurine su pomodoro migliorano le rese e l'uso dell'acqua. [Strobilurins on tomato improve yield and water use]. L'Inftore Agrar. 2017, 73, 42-45.

26. Cantore, V.; Lechkar, O.; Karabulut, E.; Sellami, M.H.; Albrizio, R.; Boari, F.; Stellacci, A.M.; Todorovic, M. Combined effect of deficit irrigation and strobilurin application on yield, fruit quality and water use efficiency of 'cherry' tomato (Solanum lycopersicum L.). Agric. Water Manag. 2016, 167, 53-61. [CrossRef] 
27. Giuliani, M.M.; Carucci, F.; Nardella, E.; Francavilla, M.; Ricciardi, L.; Lotti, C.; Gatta, G. Combined effects of deficit irrigation and strobilurin application on gas exchange, yield and water use efficiency in tomato (Solanum lycopersicum L.). Sci. Hortic. 2018, 233, 149-158. [CrossRef]

28. van Dingenen, J.; Antoniou, C.; Filippou, P.; Pollier, J.; Gonzalez, N.; Dhondt, S.; Goossens, A.; Fotopoulos, V.; Inzé, D. Strobilurins as growth-promoting compounds: How Stroby regulates Arabidopsis leaf growth. Plant Cell Environ. 2017, 40, 1748-1760. [CrossRef]

29. Amaro, A.C.E.; Ramos, A.R.P.; Macedo, A.C.; Ono, E.O.; Rodrigues, J.D. Effects of the fungicides Azoxystrobin, Pyraclostrobin and Boscalid on the physiology of Japanese cucumber. Sci. Hortic. 2018, 228, 66-75. [CrossRef]

30. Joshi, J.; Sharma, S.; Guruprasad, K.N. Foliar application of Pyraclostrobin fungicide enhances the growth, rhizobial-nodule formation and nitrogenase activity in soybean (var. JS-335). Pestic. Biochem. Physiol. 2014, 114, 61-66. [CrossRef]

31. Bonasia, A.; Conversa, G.; Lazzizzera, C.; Elia, A. Pre-harvest nitrogen and Azoxystrobin application enhances postharvest shelf-life in Butterhead lettuce. Postharvest Biol. Technol. 2013, 85, 67-76. [CrossRef]

32. Conversa, G.; Bonaria, A.; Lazzizera, C.; Elia, A. Pre-harvest nitrogen and Azoxystrobin application enhances raw product quality and post-harvest shelf-life of baby spinach (Spinacia oleracea L.). J. Sci. Food Agric. 2014, $94,3263-6272$.

33. Cassi, F.; Viviano, L. I Suoli della Basilicata-Carta pedologica della Regione Basilicata in scala 1:250.000. [The soils of Basilicata-Soil map of the Basilicata region in scale 1: 250,000]; Reg. Basilicata-Dip. Agric. Svilup. Rurale. Dir. Gen.: Potenza, Italy, 2006; 343p.

34. Cantore, V.; Iovino, F.; Pontecorvo, G. Aspetti climatici e zone fitoclimatiche della Basilicata. [Climatic aspects and phytoclimatic zones of Basilicata]; CNR-IEIF: Cosenza, Italy, 1987; Volume 2, 49p.

35. Regione Basilicata. I disciplinari di produzione integrata della Regione Basilicata 2014. [The integrated production disciplinary of the Basilicata Region 2014]; Regione Basilicata-CREA: Basilicata, Italy, 2014; 775p.

36. Todorovic, M. An Excel-based tool for real time irrigation management at field scale. In Proceedings of the International Symposium on 'Water and Land Management for Sustainable Irrigated Agriculture', Cukurova Univ., Adana, Turkey, 4-8 April 2006.

37. Allen, R.G.; Pereira, L.S.; Raes, D.; Smith, M. Crop Evapotranspiration; FAO Irrig. and Drain. Paper 56; FAO: Rome, Italy, 1998; 300p.

38. Gavilàn, P.; Castillo-Llanque, F. Estimating reference evapotranspiration with atmometers in a semiarid environment. Agric. Water Manag. 2009, 96, 465-472. [CrossRef]

39. Cantore, V.; Boari, F.; Rubino, P. Consumi idrici ed efficienza d'uso dell'acqua della ruchetta selvatica (Diplotaxis tenuifolia L. DC.). [Water consumption and water use efficiency of wild rocket (Diplotaxis tenuifolia L. DC.)]. In Proceedings of the VI Giornate Scientifiche SOI, Spoleto, Italy, 22-25 April 2002; pp. 529-530.

40. Qiu, Y.; Fu, B.; Wang, J.; Chen, L. Soil moisture variation in relation to topography and land use in a hillslope catchment of the Loess Plateau, China. J. Hydrol. 2001, 240, 243-263. [CrossRef]

41. Dobermann, A. Nutrient use efficiency-measurement and management. In Proceedings of the IFA International Workshop on Fertilizer Best Management Practices, Brussels, Belgium, 7-9 March 2007; pp. 1-28.

42. Santamaria, P.; Elia, A.; Serio, F. Effect of solution nitrogen concentration on yield, leaf element content, and water and nitrogen use efficiency of three hydroponically-grown rocket salad genotypes. J. Plant Nutr. 2002, 25, 245-258. [CrossRef]

43. Howell, T.A.; Cuenca, R.H.; Solomon, K.H. Crop yield response. In Management of Farm Irrigation Systems; Hoffman, Ed.; ASAE: Washington, DC, USA, 1995; 312p.

44. Bonasia, A.; Conversa, G.; Gonnella, M.; Serio, F.; Santamaria, P. Effects of ammonium and nitrate nutrition on yield and quality in endive. J. Hortic. Sci. Biotech. 2008, 83, 64-70. [CrossRef]

45. Gatto, M.A.; Sergio, L.; Ippolito, A.; Di Venere, D. Phenolic extracts from wild edible plants to control postharvest diseases of sweet cherry fruit. Postharv. Biol. Technol. 2016, 120, 180-187. [CrossRef]

46. Sergio, L.; Gonnella, M.; Renna, M.; Linsalata, V.; Gatto, M.A.; Boari, F.; Di Venere, D. Biochemical traits of asparagus cultivars and quality changes in two differently colored genotypes during cold storage. LWT-Food Sci. Technol. 2019, 101, 427-434. [CrossRef]

47. Wellburn, A.R. The spectral determination of chlorophyll a and chlorophyll b, as well as total carotenoids, using various solvents with spectrophotometers of different resolution. J. Plant Physiol. 1994, 144, 307-313. [CrossRef] 
48. Schiattone, M.I.; Viggiani, R.; Di Venere, D.; Sergio, L.; Cantore, V.; Todorovic, M.; Perniola, M.; Candido, V. Impact of irrigation regime and nitrogen rate on yield, quality and water use efficiency of wild rocket under greenhouse conditions. Sci. Hortic. 2018, 229, 182-192. [CrossRef]

49. Pimpini, F.; Giannini, M.; Lazzarin, R. Ortaggi da foglia da taglio. [Fresh-cut lafy vegetables]; Veneto Agricoltura: Piazzola sul Brenta, Italiy, 2005; 118p.

50. Cantore, V.; Pace, B.; Calabrese, N.; Boari, F.; Schiattone, M.I. Effects of non-woven fabric and fertilizer on air and soil temperature, leaf gas exchange, yield and quality of wild rocket grown in organic farming. Acta Hortic. 2013, 1005, 479-486. [CrossRef]

51. Hall, M.K.D.; Jobling, J.J.; Rogers, G.S. Some perspectives on rocket as a vegetable crop: A review. Veg. Crop. Res. Bull. 2012, 76, 21-41. [CrossRef]

52. Bianco, V.V.; Boari, F. Up-to-date developments on wild rocket cultivation. In Workshop 'Rocket: A Mediterranean Crop for the World', 1996 Legnaro (Padova); IPGRI: Rome, Italy, 1997; pp. 41-49.

53. Boari, F.; Cantore, V.; De Palma, E. Influenza del regime irriguo sulla ruchetta selvatica, Diplotaxis tenuifolia (L.) DC. [Influence of the irrigation regime on wild rocket, Diplotaxis tenuifolia (L.) DC.]. Proceedings of IV Giornate Scientifiche SOI, Sanremo, Italy, 1-3 April 1998; pp. 355-356.

54. Sharma, L.K.; Bali, S.K. A review of methods to improve nitrogen use efficiency in agriculture. Sustainability 2018, 10, 51. [CrossRef]

55. Wang, Z.; Li, S. Effects of nitrogen and phosphorus fertilization on plant growth and nitrate accumulation in vegetables. J. Plant Nutr. 2004, 27, 539-556. [CrossRef]

56. Zhang, J.; Sha, Z.; Zhang, Y.; Bei, Z.; Cao, L. The effects of different water and nitrogen levels on yield, water and nitrogen utilization efficiencies of spinach (Spinacia oleracea L.). Can. J. Plant Sci. 2015, 95, 671-679. [CrossRef]

57. Grossmann, K.; Kwiatkowski, J.; Casper, G. Regulation of phytohormone levels, leaf senescence and transpiration by the strobilurin Kresoxim-methyl in wheat (Triticum aestivum). J. Plant. Physiol. 1999, 154, 805-808. [CrossRef]

58. Giuliani, M.M.; Gagliardi, A.; Nardella, E.; Carucci, F.; Amodio, M.L.; Gatta, G. The effect of strobilurin on ethylene production in flowers, yield and quality parameters of processing tomato grown under a moderate water stress condition in Mediterranean area. Sci. Hortic. 2019, 249, 155-161. [CrossRef]

59. Abeles, G.B.; Morgan, P.W.; Saltveit, M.E. Ethylene in Plant Biology; Academic Press: San Diego, CA, USA, 1992.

60. Marek, J.; de Azevedo, D.; Ono, E.O.; Rodrigues, J.D.; Faria, C.M.D.R. Photosynthetic and productive increase in tomato plants treated with strobilurins and carboxamides for the control of Alternaria solani. Sci. Hortic. 2018, 242, 76-89. [CrossRef]

61. Ramos, A.R.P.; Amaro, A.C.E.; Macedo, A.C.; Souza, E.R.; Rodrigues, J.D.; Ono, E.O. Acúmulo de carboidratos no desenvolvimento de tomateiro tratado com produtos químicos. Semina. [Accumulation of carbohydrates in the development of tomato treated with chemical products]. Ciênc. Agrár. 2015, 36, 705-718. [CrossRef]

62. Viana, E.M.; Kiehl, J.C. Doses de nitrogênio e potássio no crescimento do trigo. [Nitrogen and potassium doses in wheat growth]. Bragantia 2010, 69, 975-982. [CrossRef]

63. Kluge, R.A.; Tezotto-Uliana, J.V.; Silva, P.P. Aspectos fisiológicos e ambientais da fotossíntese. [Physiological and environmental aspects of photosynthesis]. Rev. Virtual Química 2014, 7, 56-73.

64. Kopsell, D.A.; Kopsell, D.E.; Curran-Celentano, J. Carotenoid pigments in kale are influenced by nitrogen concentration and form. J. Sci. Food Agric. 2007, 87, 900-907. [CrossRef]

65. Taiz, L.; Zeiger, E. Plant Physiology; The Benjamin/Cummings Publishing Company, Inc.: Redwood City, CA, USA; Berlin, Germany, 2002; 675p.

66. Koyama, R.; Itoh, H.; Kimura, S.; Morioka, A.; Uno, Y. Augmentation of antioxidant constituents by drought stress to roots in leafy vegetables. HortTechnology 2012, 22, 121-125. [CrossRef]

67. Luoh, J.W.; Begg, C.B.; Symonds, R.C.; Ledesma, D.; Yang, R.-Y. Nutritional yield of african indigenous vegetables in water-deficient and water-sufficient conditions. Food Nutr. Sci. 2014, 5, 812-822. [CrossRef]

68. EC. Regulation (EU) No 1258/2011 of 2 December 2011 amending Regulation (EC) No. 1881/2006 as regards maximum levels for nitrates in foodstuffs. Off. J. Eur. Union L 2011, 320, 15-17.

69. Bonasia, A.; Lazzizera, C.; Elia, A.; Conversa, G. Nutritional, biophysical and physiological characteristics of wild rocket genotypes as affected by soilless cultivation system, salinity level of nutrient solution and growing period. Front. Plant Sci. 2017, 8, 1-15. [CrossRef] 
70. Signore, A.; Bell, L.; Santamaria, P.; Wagstaff, C.; Van Labeke, M.-C. Red light is effective in reducing nitrate concentration in rocket by increasing nitrate reductase activity, and contributes to increased total glucosinolates content. Front. Plant Sci. 2020, 11, 604. [CrossRef]

71. Weightman, R.M.; Huckle, A.J.; Roques, S.E.; Ginsburg, D.; Dyer, C.J. Factors influencing tissue nitrate concentration in field-grown wild rocket (Diplotaxis tenuifolia) in southern England. Food Addit. Contam. Part A Chem. Anal. Control Expo. Risk Assess. 2012, 29, 1425-1435. [CrossRef]

72. Chen, B.-M.; Wang, Z.-H.; Li, S.-X.; Wang, G.-X.; Song, H.-X.; Wang, X.-N. Effects of nitrate supply on plant growth, nitrate accumulation, metabolic nitrate concentration and nitrate reductase activity in three leafy vegetables. Plant Sci. 2004, 167, 635-643. [CrossRef]

73. Devienne-Barret, F.; Justes, E.; Machet, J.M.; Mary, B. Integrated control of nitrate uptake by crop growth rate and soil nitrate availability under field conditions. Ann. Bot. 2000, 86, 995-1005. [CrossRef]

74. Ceylan, S.; Mordogan, N.; Cakici, H.; Yoldas, F. Effects of different nitrogen levels on the yield and nitrogen accumulation in the rocket. Asian J. Plant Sci. 2002, 1, 482-483.

75. Kristensen, H.L.; Stavridou, E. Deep root growth and nitrogen uptake by rocket (Diplotaxis tenuifolia L.) as affected by nitrogen fertilizer, plant density and leaf harvesting on a coarse sandy soil. Soil Use Manag. 2017, 33, 62-71. [CrossRef]

76. Benincasa, P.; Guiducci, M.; Tei, F. The nitrogen use efficiency: Meaning and sources of variation-case studies on three vegetable crops in central Italy. HortTechnology 2011, 21, 266-273. [CrossRef]

77. Rubino, P.; Cantore, V.; Mastro, M.A. Studio dell'efficienza dell'uso dell'acqua di alcune specie erbacee in un ambiente dell'Italia meridionale. [Study of the water use efficiency of some herbaceous species in an environment of Southern Italy]. Irrig. Dren. 1999, 46, 39-46.

78. Ueno, O.; Bang, S.W.; Wada, Y.; Kondo, A.; Ishihara, K.; Kaneko, Y.; Matsuzawa, Y. Structural and biochemical dissection of photorespiration in hybrids differing in genome constitution between Diplotaxis tenuifolia $\left(\mathrm{C}_{3}-\mathrm{C}_{4}\right)$ and radish $\left(\mathrm{C}_{3}\right)$. Plant Physiol. 2003, 132, 1550-1559. [CrossRef] [PubMed]

79. Rahimi, A.; Sayadi, F.; Dashti, H.; Tajabadi Pour, A. Effects of water and nitrogen supply on growth, water-use efficiency and mucilage yield of isabgol (Plantago ovata Forsk). J. Soil Sci. Plant Nutr. 2013, 13, 341-354. [CrossRef]

80. Giuliani, M.M.; Nardella, E.; Gatta, G.; Quintadamo, M.; De Caro, A. Processing tomato cultivated under water deficit conditions: The effect of Azoxystrobin. Acta Hortic. 2011, 914, 287-294. [CrossRef]

81. Nason, M.A.; Farrar, J.; Bartlett, D. Strobilurin fungicides induce changes in photosynthetic gas exchange that do not improve water use efficiency of plants grown under conditions of water stress. Pest Manag. Sci. 2007, 63, 1191-1200. [CrossRef]

82. Gilardi, G.; Demarchi, S.; Gullino, M.L.; Garibaldi, A. Management of leaf spot of wild rocket using fungicides, resistance inducers and a biocontrol agent, under greenhouse conditions. Crop Prot. 2015, 71, 39-44. [CrossRef]

(C) 2020 by the authors. Licensee MDPI, Basel, Switzerland. This article is an open access article distributed under the terms and conditions of the Creative Commons Attribution (CC BY) license (http://creativecommons.org/licenses/by/4.0/). 